\title{
Insights on glicentin, a promising peptide of the proglucagon family
}

\author{
Juliette Raffort*1,2, Fabien Lareyre ${ }^{2,3}$, Damien Massalou ${ }^{4}$, Patrick Fénichel ${ }^{5}$, Patricia Panaïa-Ferrari ${ }^{1,2}$, Giulia Chinetti1,2 \\ ${ }^{1}$ Clinical Chemistry Laboratory, University Hospital of Nice, Nice, France \\ 2Université Côte d'Azur, Institute for Research on Cancer and Aging, Nice, France \\ ${ }^{3}$ Department of Vascular Surgery, University Hospital of Nice, Nice, France \\ ${ }^{4}$ Department of General Surgery and Digestive Cancerology, University Hospital of Nice, Nice, France \\ ${ }^{5}$ Department of Endocrinology, University Hospital of Nice, Nice, France \\ *Corresponding author: raffort.j@chu-nice.fr
}

\begin{abstract}
Glicentin is a proglucagon-derived peptide mainly produced in the L-intestinal cells. While the roles of other members of the proglucagon family including glucagon-like peptide 1, glucagon-like peptide 2 and oxyntomodulin has been well studied, the functions and variation of glicentin in human are not fully understood. Experimental and clinical studies have highlighted its role in both intestinal physiology and glucose metabolism, pointing to its potential interest in a wide range of pathological states including gastrointestinal and metabolic disorders. Due to its structure presenting many similarities with the other proglucagon-derived peptides, its measurement is technically challenging. The recent commercialization of specific detection methods has offered new opportunities to go further in the understanding of glicentin physiology. Here we summarize the current knowledge on glicentin biogenesis and physiological roles. In the limelight of clinical studies investigating glicentin variation in human, we discuss future directions for potential applications in clinical practice.
\end{abstract}

Key words: glicentin; proglucagon; glucagon-like peptide; oxyntomodulin; enteroendocrine cells

\section{Introduction}

Gastrointestinal hormones correspond to a large family of various peptides released throughout the digestive tract including the stomach, the small intestine, the bowel as well as the pancreas (1-4). Thanks to their properties, these hormones play key roles in a wide range of physiological processes including control of appetite, regulation of glucose and lipid metabolism, digestive motility, secretion or trophicity. Interestingly, some hormones derive from larger precursors called prohormones. Prohormones have minimal hormonal effects and usually represent an inactivated form of hormones, ready to be activated by post-translational modifications.

Proglucagon is the archetype of a prohormone whose post-translational processing provides vari- ous peptides with distinct and complementary biological functions. While the variations and roles of some members of the proglucagon family such as glucagon-like peptide 1 (GLP-1), glucagon-like peptide 2 (GLP-2) and oxyntomodulin are well documented, glicentin has been poorly investigated so far. Development of commercialized detection methods has recently offered new opportunities to get further in understanding the biology of this member of the proglucagon family. Here, we summarize the current knowledge on glicentin roles and pathophysiological variations. In the limelight of clinical studies, we discuss potential applications and future directions for clinical research and medical practice. 


\section{Biogenesis of glicentin}

Glicentin belongs to the proglucagon-derived peptides. The proglucagon gene is mainly expressed in the alpha-cells of the endocrine pancreas, as well as the intestinal L-cells $(4,5)$. The proglucagon gene is located on the chromosome 2 and is composed of 6 exons and 5 introns (Figure 1). The gene transcription leads to a messenger RNA (mRNA) which is translated into proglucagon, a 178 amino-acid precursor protein. While the structure of the proglucagon is identical in the pancreas and the intestine, its post-translational processing differs between these two organs, leading to various peptides, with distinct and complementary biological functions.
Schematically, the maturation in the pancreas involves the proconvertase 2 and leads to four main products: the glicentin related pancreatic polypeptide (GRPP), the glucagon, the intervening peptide-1 (IP-1) and the major proglucagon fragment (MPF) (4-8). In the enteroendocrine L-cells, post-translational processing of proglucagon, mainly mediated by proconvertases 1 and 3, liberates the glicentin, the oxyntomodulin, the GLP-1, the intervening peptide-2 (IP-2) and the GLP-2 (4,69). The mature form of glicentin is composed of 69 amino acids and contains the entire sequences of glucagon and oxyntomodulin (10).

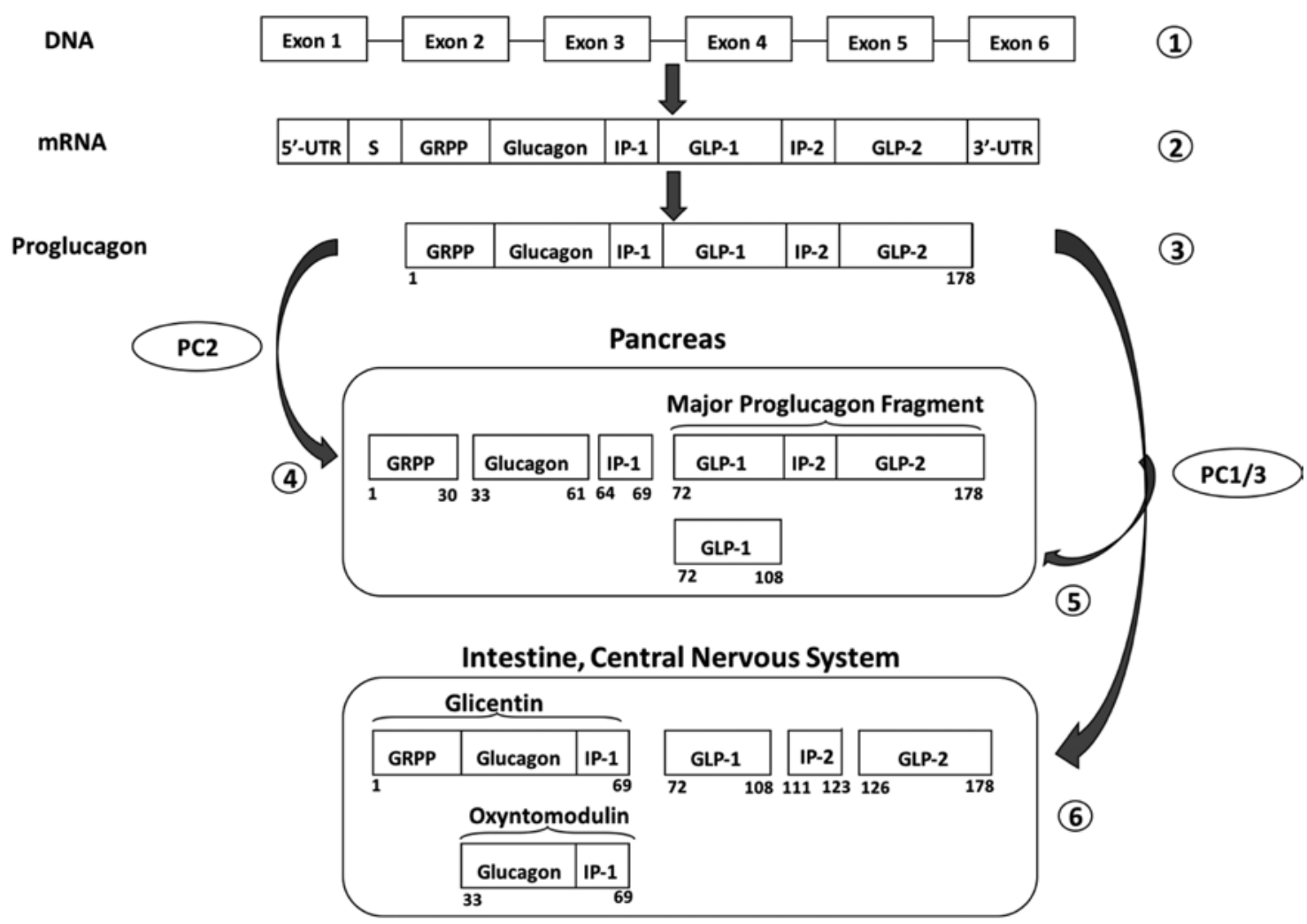

Figure 1. Processing of the proglucagon gene into proglucagon-derived peptides (modified from Baggio et al. (4), Holst et al. (5), Bataille et al. $(6,7)$, Whiting et al. (8)) and DeFronzo et al. (47)).

(1) The proglucagon gene is located on the chromosome 2 and is composed of 6 exons and 5 introns. (2) The gene transcription leads to a messenger RNA. (3) The messenger RNA (mRNA) is translated into the proglucagon, a 178 amino-acid precursor protein. (4) Posttranslational processing in the alpha pancreatic cells involves mainly the proconvertase 2 (PC2) and leads to the glicentin related pancreatic polypeptide (GRPP), the glucagon, the intervening peptide-1 (IP-1) and the major proglucagon fragment (MPF). (5) An alternative pathway involving proconvertase 1 and 3 (PC1/3) can lead to glucagon like peptide 1 (GLP-1) formation in the pancreas. (6) In the enteroendocrine L-cells and in the central nervous system, post-translational processing of proglucagon is mediated by proconvertases 1 and 3 and liberates the glicentin, the oxyntomodulin, the glucagon like peptide 1, the Intervening Peptide-2 (IP-2) and the glucagon like peptide 2 (GLP-2). DNA - deoxyribonucleic acid. 
As the enteroendocrine L-cells are present from duodenum to rectum, glicentin can potentially be synthetized all along the digestive tract. Nevertheless, L-cells are rare before the terminal ileum and experiments in animal models revealed that tissue concentration of oxyntomodulin/glicentin were higher in distal ileum, caecum, and proximal colon compared to duodenum and proximal jejunum $(11,12)$. These results suggest that the distal small bowel and the proximal colon are the main sites of the glicentin synthesis.

Nevertheless, recent advances in the study of molecular mechanisms have unravelled previously unsuspected pathways. Indeed, several studies have highlighted that alpha pancreatic cells express proconvertase 1 and 3 and are able to produce and secrete GLP-1 $(13,14)$. Further, an immature form of glicentin has been identified in the alpha cells (6). Interestingly, the proglucagon gene is also expressed by specific neurons in the central nervous system. Its post-translational processing is similar to the intestine and mature glicentin thus has been identified in the central nervous system (6). Hence, it is not excluded that future research on glicentin biogenesis could reveal new sites and pathways involved in its production.

\section{Glicentin and intestinal physiology}

Experimental studies in several animal models including piglets, dogs and rats have reported the role of glicentin in intestinal physiology (Table 1).

First, glicentin secretion is stimulated by food intake as revealed by increased plasma glicentin concentrations after glucose, lipids and amino-acids loading into the duodenum (15-17). Several studies in rat model have highlighted the trophic role of glicentin on intestinal mucosa. Indeed, an increase of several parameters of mucosal growth, including weight, protein and DNA content, alkaline phosphatase and ornithine decarboxylase activities have been reported in the jejunum after glicentin subcutaneous injection (18). In vitro studies confirmed the proliferative action of glicentin on epithelial cell line IEC-6. Another study showed the trophic effect induced by glicentin in the small intestine, with a more pronounced effect in the ileum (19), whereas Myojo et al. did not observe any effect of glicentin in the ileum (18). These heterogeneous results could be, at least partly, explained by differences in the methodology used including rat feeding, glicentin concentration and administration as well as markers used to assess intestinal proliferation. The authors further revealed a de-

TABLE 1. Summary of experimental studies on glicentin functions and variation

\begin{tabular}{|c|c|c|c|c|}
\hline Functions & Models & Aim & Main results & References \\
\hline \multirow{3}{*}{$\begin{array}{l}\text { Factors } \\
\text { stimulating } \\
\text { glicentin } \\
\text { secretion }\end{array}$} & $\begin{array}{l}\text { - Piglets - administration } \\
\text { of butter, glycerol and } \\
\text { sodium palmitate into } \\
\text { the duodenum }\end{array}$ & $\begin{array}{l}\text { Investigate the response } \\
\text { of plasma glicentin to } \\
\text { intraluminal fat loading. }\end{array}$ & $\begin{array}{l}\text { - Increase of plasma glicentin following } \\
\text { butter and palmitate administration } \\
\text { - Slight increase of plasma glicentin, } \\
\text { but not significant following glycerol } \\
\text { administration }\end{array}$ & $\begin{array}{l}\text { Ohneda et } \\
\text { al. (15) }\end{array}$ \\
\hline & $\begin{array}{c}\text { - Piglets - administration } \\
\text { of a mixture of } 10 \\
\text { amino acids into the } \\
\text { duodenum } \\
\text { - Dogs - pancreatectomy, } \\
\text { administration of } \\
\text { arginine }\end{array}$ & $\begin{array}{l}\text { Explore the effect of } \\
\text { amino acids on glicentin } \\
\text { secretion. }\end{array}$ & $\begin{array}{l}\text { - Increase of plasma glicentin following } \\
\text { amino acids administration } \\
\text { - Increase of total immunoreactive } \\
\text { glucagon in pancreatectomized dogs } \\
\text { following amino acids administration } \\
\text { Administration of amino acids enhances } \\
\text { glicentin secretion from the gut. }\end{array}$ & $\begin{array}{l}\text { Ohneda et } \\
\text { al. (16) }\end{array}$ \\
\hline & $\begin{array}{l}\text { - Piglets - administration } \\
\text { of glucose into the } \\
\text { duodenum }\end{array}$ & $\begin{array}{l}\text { Investigate the } \\
\text { secretion of glicentin in } \\
\text { response to intraluminal } \\
\text { administration of } \\
\text { glucose. }\end{array}$ & $\begin{array}{l}\text { - Increase of plasma glicentin after } \\
\text { glucose loading }\end{array}$ & $\begin{array}{l}\text { Ohneda et } \\
\text { al. (17) }\end{array}$ \\
\hline
\end{tabular}


- Rats - subcutaneous injection of glicentin $(50 \mu \mathrm{g} / \mathrm{kg}$ every $12 \mathrm{~h}$ for 2 weeks)

- In vitro - intestinal epithelial cell line IEC-6, incubation with glicentin (0-1000 ng/ $\mathrm{mL}$ ) for $48 \mathrm{~h}$
Examine the trophic effects of glicentin on small-intestinal mucosa and on the small-intestinal epithelial cell line IEC-6
- Jejunum - increase of weight, protein, DNA content and alkaline phosphatase activity in animals who were injected with glicentin; increase of ornithine decarboxylase activity after intraperitoneal injection of glicentin

- lleum - no difference between animals injected with glicentin and the control

Myojo et al. group

- In vitro - increase of tritium-thymidine incorporation and the number of IEC- 6 cells in presence of glicentin

Trophic effect of glicentin on intestinal mucosa.
- Dose-dependent increase of mucosal proliferation in the small intestine induced by glicentin, with an effect more pronounced in the ileum
- Rats - parenteral nutrition for 6 days and administration of $1,4,20$ or $80 \mu \mathrm{g} /$ rat of glicentin via the jugular vein
Examine the effects of glicentin on intestinal proliferation in vivo in the rat.

\section{Effect of glicentin on intestinal trophicity}

- Rats - resection of the small intestine and aministration of methionyl rat glicentin (20 $\mu /$ day/rat) from the second day after the operation and during 28 days using miniosmotic pumps
Explore the effects of glicentin on intestinal adaptive responses to $70 \%$ resection of small intestine in rats
- Decreased crypt fission of the ileum in the 20 and $80 \mu \mathrm{g}$ glicentin groups compared to controls

- No significant effect of glicentin on proliferation or fission in the colon Trophic effect of glicentin on the small intestine but not on the colon.
- Rats with $70 \%$ distal intestinal resection - significant increase of the weight of the residual duodenum and its mucosal weight, protein, and diamine oxydase activity compared to controls. No significant change on the residual jejunum.

- Rats with $70 \%$ proximal intestinal resection - significant increase of the weight of the residual duodenum and its mucosal weight, protein, and diamine oxydase activity compared to controls

Stimulating activity of glicentin on the adaptive responses to massive intestinal resection.
Sasaki et al.

Hirotani et

- Effect of glicentin in the jejunal TVF group - increase of mucosal growth measurements in the TVF and the intact jejunum mucosa may be caused by a combination of non-luminal and luminal factors.

- Effect of glicentin in the ileal TVF group - stimulation of the proliferation of intact ileal mucosa but no effect on et al. (24)
Effects of glicentin on the proximal gut the luminal stream and subcutaneous injection of glicentin $(50 \mu \mathrm{g} / \mathrm{kg}$ every 12 hours for 1 week)
Determine whether the trophic effect of glicentin is mediated by mechanism involving luminal or non-luminal factors and determine whether glicentin exerts a differential trophic mucosa effect on jejunal or ileal
Effect on the ileal mucosa may be influenced by luminal contents and endogenous secretions.

Differential trophic effect of glicentin on mucosa of the proximal jejunum and distal ileum. 


\begin{tabular}{|c|c|c|c|c|}
\hline \multirow{2}{*}{$\begin{array}{l}\text { Effect of glicentin } \\
\text { on bacterial } \\
\text { internalization } \\
\text { and Helicobacter } \\
\text { pylori infection }\end{array}$} & $\begin{array}{l}\text { - Cell line, in vitro } \\
\text { INT-407 cell lines - } \\
\text { incubation of glicentin } \\
(100 \mathrm{ng} / \mathrm{ml} \text { to } 1 \mu \mathrm{g} / \mathrm{ml}) \\
\text { for } 24 \mathrm{~h} \\
\text { - Assays on bacterial } \\
\text { internalization with } \\
\text { Salmonella enteritidis } \\
\text { IFO } 3313, \text { Escherichia } \\
\text { coli ATCC M44 and } \\
\text { Enterococcus faecalis } \\
\text { ATCC } 29212\end{array}$ & $\begin{array}{l}\text { Determine the effect } \\
\text { of recombinant human } \\
\text { glicentin on bacterial } \\
\text { internalization by } \\
\text { confluent enterocytes }\end{array}$ & $\begin{array}{l}\text { - Lower bacterial internalization } \\
\text { through the glicentin-treated } \\
\text { enterocytes than the non-treated } \\
\text { - Dose dependent effect of glicentin on } \\
\text { bacterial internalization in the range } \\
\text { from } 500 \text { to } 1 \mu \mathrm{g} / \mathrm{mL} \\
\text { Glicentin acts as a barrier-sustaining } \\
\text { agent that inhibits extra-intestinal } \\
\text { invasion of enteric bacteria and } \\
\text { decreased bacterial translocation. }\end{array}$ & $\begin{array}{l}\text { Chiba et al. } \\
\text { (25) }\end{array}$ \\
\hline & $\begin{array}{l}\text { - Human gastric } \\
\text { biopsies - } 7 \text { cases with } \\
\text { endoscopical intestinal } \\
\text { metaplasia; } 47 \text { cases } \\
\text { with no endoscopical } \\
\text { intestinal metaplasia } \\
\text { - } 18 \text { biopsies with } \\
\text { histological intestinal } \\
\text { metaplasia } \\
\text { - } 29 \text { biopsies with no } \\
\text { intestinal metaplasia }\end{array}$ & $\begin{array}{l}\text { Investigate the } \\
\text { relationship between } \\
\text { Helicobacter pylori } \\
\text { infection, intestinal } \\
\text { metaplasia and } \\
\text { glicentin expression in } \\
\text { the gastric mucosa }\end{array}$ & $\begin{array}{l}\text { Detection of mRNA glicentin } \\
\text { expression in } 100 \% \text { of cases with } \\
\text { endoscopical intestinal metaplasia, in } \\
76,7 \% \text { of cases with no endoscopical } \\
\text { intestinal metaplasia } \\
\text { - Glicentin mRNA expression statistically } \\
\text { associated with the existence of } \\
\text { histological intestinal metaplasia and } \\
\text { positively correlated with Helicobacter } \\
\text { pylori infection }\end{array}$ & $\begin{array}{l}\text { Ishihara et } \\
\text { al. (33) }\end{array}$ \\
\hline \multirow{4}{*}{$\begin{array}{l}\text { Effect of } \\
\text { glicentin on } \\
\text { gastro-intestinal } \\
\text { motility }\end{array}$} & $\begin{array}{l}\text { Rats - glicentin IV } \\
\text { infusion during the } 5 \\
\text { min preceding food } \\
\text { onset and during the } \\
\text { first } 15 \text { min of food } \\
\text { intake }\end{array}$ & $\begin{array}{l}\text { Investigate the effect } \\
\text { of a systemic increase } \\
\text { of glicentin on food } \\
\text { intake, postprandial } \\
\text { myoelectrical activity } \\
\text { in duodenum, jejunum } \\
\text { and ileum and the } \\
\text { oro-caecal transit }\end{array}$ & $\begin{array}{l}\text { - No effect of systemic injection of } \\
\text { glicentin on food intake } \\
\text { - Reduction of duration of the } \\
\text { postprandial myoelectrical activity on } \\
\text { duodenum and jejunum induced by } \\
\text { glicentin }\end{array}$ & $\begin{array}{l}\text { Pellissier et } \\
\text { al. (26) }\end{array}$ \\
\hline & $\begin{array}{l}\text { Dogs - use of vagally } \\
\text { denervated gastric } \\
\text { pouches equipped } \\
\text { with four strain gauge } \\
\text { force transducers } \\
\text { on the pouch, } \\
\text { gastric body, antrum } \\
\text { and duodenum. } \\
\text { Injection of glicentin } \\
\text { intra-veinously } \\
(1 \mathrm{nmol} / \mathrm{kg})\end{array}$ & $\begin{array}{l}\text { Explore the effect } \\
\text { of glucagon, GLP-1, } \\
\text { GLP-2 and glicentin on } \\
\text { gastroduodenal motility } \\
\text { and their mechanisms } \\
\text { of action }\end{array}$ & $\begin{array}{l}\text { - Glicentin did not affect } \\
\text { motilin-induced phase III contractions } \\
\text { at any site } \\
\text { - Glucagon inhibited contractions in the } \\
\text { pouch and the stomach } \\
\text { - GLP- } 1 \text { inhibited contractions at all sites } \\
\text { - GLP-2 inhibited contractions in the } \\
\text { pouch } \\
\text { Differential effect of proglucagon-related } \\
\text { peptides on gastroduodenal motility. }\end{array}$ & $\begin{array}{l}\text { Shibata et } \\
\text { al. (48) }\end{array}$ \\
\hline & $\begin{array}{l}\text { Rabbit, in vitro - } \\
\text { isolation of smooth } \\
\text { muscle cells (SMCs) } \\
\text { from rabbit antrum, } \\
\text { incubation with } \\
\text { glicentin }(5 \mathrm{nmol} / \mathrm{L})\end{array}$ & $\begin{array}{l}\text { Explore the effect } \\
\text { of glicentin SMCs } \\
\text { contraction isolated } \\
\text { from the rabbit antrum }\end{array}$ & $\begin{array}{l}\text { - Induction of SMCs contraction by } \\
\text { glicentin } \\
\text { - Maximal contraction at } 30 \mathrm{~s}\end{array}$ & $\begin{array}{l}\text { Rodier et al. } \\
\quad(29)\end{array}$ \\
\hline & $\begin{array}{l}\text { Rabbit, in vitro - } \\
\text { isolation of SMCs } \\
\text { from rabbit antrum, } \\
\text { incubation with } \\
\text { glicentin }(2 \mathrm{nmol} / \mathrm{L})\end{array}$ & $\begin{array}{l}\text { Describe the } \\
\text { morphological } \\
\text { and functional } \\
\text { characteristics } \\
\text { of a model of } \\
\text { cultured digestive } \\
\text { SMCs exhibiting } \\
\text { a differentiated } \\
\text { phenotype }\end{array}$ & $\begin{array}{l}\text { - Induction of SMCs contraction by } \\
\text { glicentin }\end{array}$ & $\begin{array}{l}\text { Jarousse et } \\
\text { al. (30) }\end{array}$ \\
\hline
\end{tabular}


- Rabbit, in vitro isolation of SMCs from rabbit antrum, incubation with glicentin $(0.3 \mathrm{nmol} / \mathrm{L})$
Investigate the modifications of the calcium/ phosphoinositide and the cyclic adenosine monophosphate (CAMP) pathways in rabbit antral SMCs
- Induction of SMCs contractions by glicentin

- Induction of a biphasic and rapid inositol $(1,4,5)$-trisphosphate (Ins $(1,4,5)$ P3) production by glicentin

- In the absence of extracellular calcium: glicentin induced Ins(1,4,5)P3 production became monophasic

- Induction of a rapid increase of intracellular free calcium induced by glicentin

- Reduction of the CAMP content by glicentin of cells stimulated by forskolin

- Contractile effect of glicentin potentially mediated by stimulation of the phosphoinositide hydrolysis and inhibition of CAMP production

- Action of glicentin potentially mediated by receptor coupled to $G$ proteins

\section{Effect of}

glicentin on

\section{gastro-intestinal} motility
- Inhibition of contraction reaction by glicentin after blockade of the adrenergic and cholinergic nerve

- Human, in vitro - 32 Investigate the enteric preparations of human nervous responses to normal jejunal muscle strips glicentin in the normal small bowel

- Regulating inhibition of the contraction reaction in normal human jejunum via non-adrenergic non-cholinergic (NANC) nerves, and has a direct action on the jejunal muscle receptor.

- Human SMCs from colon dose-related contraction of SMCs induced by glicentin. Decrease of contractile activity induced by glicentin when incubated with exendin-(9-39), a selective antagonist of GLP-1 receptor

Ayachi et al. Investigate the effect of glicentin on the motor activity of colon

- Rabbit SMCs from antrum -

right colons, 14 colons); isolation of SMCs

- Rabbit - SMCs from antrum exendin-(9-39) dose dependently reduced the contractile activity of glicentin

Effect of glicentin in SMC contraction may be mediated by GLP-1 receptor.

\begin{tabular}{|c|c|c|c|c|}
\hline $\begin{array}{l}\text { Effect of glicentin } \\
\text { on gastric acid } \\
\text { secretion }\end{array}$ & $\begin{array}{l}\text { Rats - use of chronic } \\
\text { gastric fistulas, } \\
\text { stimulation of gastric } \\
\text { acid secretion } \\
\text { by pentagastrin, } \\
\text { injection of glicentin } \\
\text { intra-veinously (bolus } \\
3 \mu \mathrm{g} / \mathrm{kg} \text {, followed by } \\
600 \mathrm{ng} / \mathrm{h} \text { or } 120 \mathrm{ng} / \mathrm{h} \text { ) }\end{array}$ & $\begin{array}{l}\text { Investigate the role of } \\
\text { glicentin on gastric acid } \\
\text { secretion }\end{array}$ & $\begin{array}{l}\text { - Inhibition of gastric acid secretion by } \\
\text { glicentin }\end{array}$ & $\begin{array}{l}\text { Kirkegaard } \\
\text { et al. (32) }\end{array}$ \\
\hline
\end{tabular}


- Rats, in vitro - isolation of hepatocytes
Study the effect of glicentin on the glucos production and CAMP accumulation of isolated hepatocytes

- Glicentin and glucagon stimulated the release of glucose from hepatocytes into the medium

- Stimulation of CAMP production by glucagon and glicentin

- Degradation of glicentin into low molecular weight fragments during incubation with hepatocytes, with some fragments similar to glucagon

- Plasmatic concentrations after glicentin (1-16) administration in the canine pancreas - decrease of glucagon local circulation in canine pancreas; administration of glicentin into the pancreaticoduodenal artery (400 ng for 10 $\min )$

Investigate the effect of glicentin-related peptides on the endocrine pancreatic function
- Plasmatic concentrations after glicentin (62-69) administration in the canine pancreas - decrease of insulin and glucagon

Glicentin released during nutrient intake might inhibit the secretion of glucagon.
Ohneda et

Thieden et

al. (35)

al. (36)

- Plasmatic concentrations after glicentin (1-16) and glicentin (62-69) administration in the canine pancreas

- Dogs - use of in vivo local circulation in canine pancreas; administration of glicentin into the

Effect of glicentin on glucose metabolism pancreaticoduodenal artery $(200$ pmol for $10 \mathrm{~min}$ )
Study the role of glicentin-related peptides on the endocrine pancreas - increase of insulin and decrease of glucagon

- Plasmatic concentrations after glicentin (62-69) administration in the canine pancreas - increase of insulin

Ohneda et and decrease of glucagon

- Maximum response of insulin and glucagon within $20 \mathrm{~min}$ after glicentin (1-16) and glicentin (62-69) administration - increase of insulin and decrease of glucagon

- Plasmatic concentrations after glicentin administration at a dose of $100 \mathrm{pmol}$ during glucose infusion - no significant change in blood glucose, slight increase of insulin, but not significant; no significant change of glucagon

- Plasmatic concentrations after glicentin administration at a dose of $400 \mathrm{pmol}$ during glucose infusion - significant

- Dogs - use of in vivo local circulation in canine pancreas; administration of glicentin into the pancreaticoduodenal artery (100 and 400 pmol for $10 \mathrm{~min}$ )
Explore the effect of human recombinant glicentin on the endocrine function of the pancreas increase of blood glucose, significant increase of insulin, increase of glucagon

- Plasmatic concentrations after glicentin administration at a dose of 100 pmol during arginine infusion - no significant change in blood glucose, significant increase of insulin, no significant change of glucagon

- Plasmatic concentrations after glicentin administration at a dose of $400 \mathrm{pmol}$ during arginine infusion - no significant change in blood glucose, significant increase of insulin, increase of glucagon Demonstration of the insulinotropic action of glicentin.
Ohneda et

al. (37)

GLP $1 / 2$ - glucagon like peptide 1 and 2 . 
crease of crypt fission in the ileum after glicentin administration (19). Crypt fission corresponds to the mechanism leading to new crypt formation and plays a major role in intestinal development. Increased crypt fission is observed following intestinal damage or ulceration (20), after administration of chemical carcinogens in rats and in humans with precancerous defects $(21,22)$. Even if further investigations are required for a better understanding of the physiological significance of decreased crypt fission, these results pinpoint the potential role of glicentin in intestinal mucosa remodelling. The observation that glicentin is involved in mechanisms regulating mucosa development and renewal, has led some investigators to explore the effect of glicentin on adaptive response to intestinal resection (23). A significant increase of the weight of the residual duodenum and its mucosal weight, protein, and diamine oxidase activity was found in rats which underwent a $70 \%$ distal intestinal resection and which received glicentin after the intervention compared to control animals. These results underline the trophic role of glicentin in intestinal post-surgery remodelling. To go further into the physiological mechanisms, some authors aimed to determine whether the trophic effect of glicentin was mediated through pathways involving luminal or non-luminal factors (24). To achieve this goal, they used a model of rats with a construction of loops of jejunum and ileal fistulas that were isolated from the luminal stream. The authors found an increase of mucosal growth measurements in both the jejunal fistula and the intact jejunum, suggesting that the effect of glicentin on the proximal gut mucosa may be caused by a combination of non-luminal and luminal factors. In contrast, glicentin stimulated the proliferation of intact ileal mucosa but had no effect in the ileal fistula, meaning that the effect of glicentin on the ileal mucosa may be influenced by luminal content and endogenous secretions. Taken together, these results suggest a differential trophic effect of glicentin on mucosa on the proximal jejunum and distal ileum. In addition to its trophic effect on intestinal mucosa, glicentin may also act as a barrier-sustaining agent. Indeed, the effect of recombinant human glicentin on bac- terial internalization by confluent INT407 enterocytes cell lines using Salmonella enteritidis, Escherichia coli and Enterococcus faecalis was determined (25). A lower bacterial internalization through the glicentin-treated enterocytes was observed compared to the non-treated cells, revealing the inhibitory effect of glicentin on bacterial translocation and intestinal invasion.

Intestinal motility represents a factor potentially influencing bacterial internalization. In vivo studies in animal models highlighted the effect of glicentin on gut motility, as demonstrated by the reduction of the duration of the postprandial myoelectrical activity on duodenum and jejunum in rats infused by glicentin (26). Ex vivo studies using preparation of human normal jejunal muscle strips further revealed the inhibitory effect of glicentin on contraction reaction after blockade of the adrenergic and cholinergic nerve (27). In contrast, studies on smooth muscle cells (SMCs) isolated from rabbit antrum revealed the stimulatory action of glicentin on muscle contraction (28-30). This contractile effect of glicentin may be potentially mediated by receptor coupled to $G$ proteins and through the stimulation of the phosphoinositide hydrolysis and cyclic adenosine monophosphate (CAMP) production (28). Further, a reduced contractile activity of glicentin was observed after incubation with exendin-(9-39), a selective antagonist of GLP-1 receptor, suggesting that glicentin action may be relayed, at least partly, through GLP-1 receptor (31). Similarly to what was observed using SMCs from rabbit antrum, a dose-related contraction of SMCs isolated from human colon was found and this effect was inhibited after incubation with exendin-(9-39) (31). Taken together, these results reveal the stimulating role of glicentin on SMC contraction along the digestive tract, an effect which may involve GLP-1 receptor. At last, a study in rats revealed the inhibitory effect of glicentin on gastric acid secretion (32). Based on its action on the stomach, some investigators aimed at exploring the role of glicentin in metaplasia and its relationship with Helicobacter pylori infection (33). Using human gastric biopsies, they revealed that glicentin mRNA expression was associated with the existence of histological intes- 
tinal metaplasia and positively correlated with $\mathrm{Hel}-$ icobacter infection. Even if given its biological function, glicentin is of potential interest in the context of digestive oncology, these results should be interpreted with caution. In this study, mRNA glicentin expression was assessed, which means that the expression of the precursor proglucagon and not the mature glicentin form was analysed. Further investigations on glicentin protein expression would be required for a better understanding of its role and variation in context of intestinal metaplasia. To summarize, glicentin plays paracrine functions on the digestive tract through its involvement in various processes including regulation of intestinal trophicity and motility, as well as gastric acid secretion. Its potential implication in various pathophysiological conditions including cancers, infectious or inflammatory diseases remains to be explored.

\section{Glicentin and glucose metabolism}

The family of proglucagon-derived peptides plays a major metabolic role through their involvement in glucose homeostasis. Glucagon is well known for its hyperglycemic action (6). On the opposite, main proglucagon-derived hormones produced in the intestine indirectly balance the effect of glucagon by exerting hypoglycemic actions. GLP-1 stimulates insulin secretion, improves insulin sensitivity and suppresses the release of glucagon $(3,7)$. Oxyntomodulin has also a positive effect on insulin secretion $(2,3)$. The role of GRPP in glucose metabolism has been less studied and is more controversial. Indeed, a few decades ago, Ohneda et al. observed an increase of plasma insulin concomitantly with a decrease of glucagon after GRPP administration into the pancreaticoduodenal artery in dogs, suggesting an incretin-like effect (34). However, a recent report revealed that GRPP inhibited glucose-stimulated insulin secretion from the isolated pancreas of adult male rats (8). The discrepancy between these two studies could be, at least partly, explained by differences in methodology used including species studied, GRPP synthesis and administration or pancreas preparation. This underlines the real need of further research to fully understand the specific role of each member of the proglucagon family.

In that context, glicentin effect was also investigated (Table 1). A first study found that glicentin stimulated the release of glucose from rat hepatocytes, with a stimulation of CAMP production, an effect comparable to what observed after incubation with glucagon (35). The authors observed that during incubation with hepatocytes glicentin was degraded into low molecular weight fragments, some being very similar to glucagon, addressing the question whether glicentin could exert glucagon-like effects through a possible degradation to glucagon. Nevertheless, these results should be interpreted with caution since this study was performed 30 years ago and since then the sequence defining glicentin protein as well as the technologies to identify and purify it have largely evolved. In fact, several relatively more recent in vivo studies in dogs demonstrated that administration of glicentin led to an increase of plasma insulin and a decrease of glucagon $(34,36,37)$. Hence, similarly to GLP-1 and oxyntomodulin, glicentin has an insulinotropic action and exert an incretin-like effect. Even if the precise mechanisms involved in the insulin-releasing action of glicentin remains to be elucidated, these results pinpoint the potential interest of glicentin as marker and/or player of metabolic diseases such as diabetes or obesity.

\section{Circulating glicentin in humans}

Given the role of glicentin in both intestinal physiology and glucose metabolism, its potential interest as non-invasive biomarker including digestive and metabolic diseases would be worth investigating. Due to its structure, assessment of circulating glicentin concentration is challenging to obtain a specific measurement which does not cross react with other proglucagon-derived peptides. Indeed, glicentin peptide contains the entire sequence of glucagon, GRPP and oxyntomodulin (Figure 1). This technical reason combined with the lack of commercialized methods to measure glicentin until recently contribute to explain why literature on circulating glicentin in human is poor and its variation not fully elucidated. 
The first published reports investigated circulating glicentin concentration using a non-commercialized radioimmunoassay associated with chromatography (38) and a non-commercialized sandwich enzyme-linked immunosorbent assay (ELISA) (Table 2) (39-41). In the latest assay, the authors used two antibodies against the GRPP and the glucagon sequences and proved the specificity of the method to measure glicentin. Based on these studies, a solid phase two-site enzyme ELISA kit has recently been commercialized (Mercodia ${ }^{\circledast}$, Uppsala, Sweden) and was used in several studies (42-44). The manufacturer tested the specificity of the assay and did not detect any cross reactivity with glucagon, oxyntomodulin, mini-glucagon, GLP-1 and GLP-2. At last, another commercialized ELISA kit has been developed (Merck-Millipore ${ }^{\circledR}$, Billerica, United States) and was used in one study

TABLE 2. Methodology used to measure fasting circulating glicentin concentrations in human

\begin{tabular}{|c|c|c|c|c|c|}
\hline \multirow[b]{2}{*}{ Detection method } & \multirow[b]{2}{*}{ Sample } & \multirow[b]{2}{*}{ Population } & \multicolumn{2}{|c|}{ Glicentin concentration (pmol/L) } & \multirow[b]{2}{*}{ References } \\
\hline & & & $\begin{array}{l}\text { Median } \\
\text { (interquartile } \\
\text { range) }\end{array}$ & $\begin{array}{l}\text { Mean } \\
\pm \text { standard } \\
\text { error mean }\end{array}$ & \\
\hline $\begin{array}{l}\text { Commercialized ELISA } \\
\text { technique } \\
\text { (Merck- Millipore }^{\oplus} \text { ) } \\
\text { - Inter-assay variation: }<15 \% \\
\text { - Intra-assay variation: }<10 \%\end{array}$ & Plasma & $\begin{array}{l}\text { Patients who had acute pancreatitis } \\
\qquad(\mathrm{N}=83)\end{array}$ & $\begin{array}{c}6.2 \\
(3.0-16.7)\end{array}$ & - & $\begin{array}{l}\text { Pendharkar } \\
\text { et al. (45) }\end{array}$ \\
\hline \multirow{3}{*}{$\begin{array}{l}\text { Commercialized ELISA } \\
\left.\text { technique (Mercodia }{ }^{\oplus}\right) \\
\text { - Detection limit: } 3 \text { pmol/L } \\
\text { - Inter-assay variation: }< \\
10.8 \% \\
\text { - Intra-assay variation: }<8 \%\end{array}$} & Plasma & $\begin{array}{l}\text { - Lean adolescents }(\mathrm{N}=19) \\
\text { - Adolescents with obesity and } \\
\text { normal glucose tolerance }(\mathrm{N}=23) \\
\text { - Adolescents with obesity and im- } \\
\text { paired glucose tolerance }(\mathrm{N}=19) \\
\text { - Adolescents with obesity and } \\
\text { type } 2 \text { diabetes }(\mathrm{N}=4)\end{array}$ & $\begin{array}{c}17.6(13-25) \\
23.6(17.7-32.8) \\
18.2(8.6-21.8) \\
15.1(13.3-18)\end{array}$ & - & $\begin{array}{l}\text { Manell et al. } \\
\text { (42) }\end{array}$ \\
\hline & \multirow[b]{2}{*}{ Serum } & $\begin{array}{c}\text { - Lean adults }(\mathrm{N}=52) \\
\text { - Adults with severe or morbid } \\
\text { obesity }(\mathrm{N}=39)\end{array}$ & $\begin{array}{l}24(18-38) \\
12(7.6-17)\end{array}$ & - & $\begin{array}{l}\text { Raffort et al. } \\
\text { (44) }\end{array}$ \\
\hline & & $\begin{array}{c}\text { - Adults with severe or morbid } \\
\text { obesity before Roux-en-Y Gastric } \\
\text { Bypass (RYGB) surgery }(\mathrm{N}=18) \\
\text { - Adults } 12 \text { months after RYGB sur- } \\
\text { gery }(\mathrm{N}=18) \\
\text { - Adults with severe or morbid } \\
\text { obesity before Laparoscopic } \\
\text { Sleeve Gastrectomy (LSG)† sur- } \\
\text { gery }(\mathrm{n}=12) \\
\text { - Adults } 12 \text { months after LSG sur- } \\
\text { gery }(\mathrm{n}=12)\end{array}$ & - & $\begin{array}{c}14 \pm 3.6 \\
19.7 \pm 2.7 \\
12.5 \pm 1.4 \\
16.4 \pm 1.8\end{array}$ & $\begin{array}{l}\text { Raffort et al. } \\
\text { (43) }\end{array}$ \\
\hline \multirow{3}{*}{$\begin{array}{l}\text { Non-commercialized } \\
\text { sandwich ELISA } \\
\text { - Detection limit: } 3.8 \mathrm{pmol} / \mathrm{L} \\
\text { - Inter-assay variation: < 8\% } \\
\text { - Intra-assay variation: < 5\% }\end{array}$} & \multirow{3}{*}{ Plasma } & $\begin{array}{l}\text { - Diabetic patients }(\mathrm{N}=119) \\
\quad \text { - Controls }(\mathrm{N}=6)\end{array}$ & - & $\begin{array}{l}19.7 \pm 2.1 \\
18.6 \pm 4.7\end{array}$ & $\begin{array}{l}\text { Naito et al. } \\
\text { (39) }\end{array}$ \\
\hline & & $\begin{array}{l}\text { - Very-low-birthweight infants (N } \\
\qquad=21)\end{array}$ & NV & NV & $\begin{array}{l}\text { Shimizu et } \\
\text { al. (41) }\end{array}$ \\
\hline & & - Children $(\mathrm{N}=119)$ & NV & NV & $\begin{array}{c}\text { Tadokoro et } \\
\text { al. (40) }\end{array}$ \\
\hline $\begin{array}{l}\text { Non-commercialized } \\
\text { radioimmunoassay and } \\
\text { chromatography }\end{array}$ & Plasma & $\begin{array}{c}\text { - Non insulin-dependent diabetic } \\
\text { patients }(\mathrm{N}=8) \\
\text { - } \quad \text { Controls }(\mathrm{N}=8)\end{array}$ & NV & NV & $\begin{array}{l}\text { Orskov et al. } \\
\text { (38) }\end{array}$ \\
\hline
\end{tabular}

RYGB: Roux-en-Y Gastric Bypass. LSG: Laparoscopic Sleeve Gastrectomy. NV - no exact values. 
(45). The different ELISA tests share similarities, with detection limit for human glicentin close to 3 $\mathrm{pmol} / \mathrm{L}$, inter-assay variation less than $15 \%$ and intra-assay variation less than $10 \%$ (Table 2), allowing the comparison of results among different studies. However, data regarding pre-analytical conditions are to date extremely poor. According to results provided by manufacturers, higher glicentin concentrations were obtained when using dipeptidyl peptidase-4 inhibitor while protease and esterase inhibitors did not seem to have an effect on glicentin stability. Hence, when comparing results among different studies, it should be taken into consideration that methodology used for sample collection and preservation could have potentially impacted on glicentin concentrations.

The studies published so far confirmed the stimulating effect of glucose ingestion on glicentin secretion, as demonstrated by higher glicentin concentration after oral glucose tolerance test (OGTT) compared to fasting concentrations $(38,39,42)$ (Table 3). Besides, similarly to what was observed in animal models, food intake stimulates glicentin secretion, as revealed by higher glicentin concentrations after feeding in children $(40,41)$. As animal models demonstrated the role of glicentin in intestinal mucosa growth and trophicity, some authors investigated its variation in children from birth to

TABLE 3. Summary of studies on circulating glicentin variation in human

\begin{tabular}{|c|c|c|c|c|}
\hline Population & Aim & $\begin{array}{l}\text { Glicentin } \\
\text { detection method }\end{array}$ & Main results & References \\
\hline $\begin{array}{l}\text { - } 83 \text { patients who had } \\
\text { acute pancreatitis: } 30 \\
\text { developed abnormal } \\
\text { glucose metabolism, } \\
53 \text { kept normal glucose } \\
\text { metabolism }\end{array}$ & $\begin{array}{l}\text { Explore the } \\
\text { relationships } \\
\text { between } \\
\text { peptides known } \\
\text { to be produced } \\
\text { in both gut and } \\
\text { brain and glucose } \\
\text { metabolism in } \\
\text { patients after } \\
\text { acute pancreatitis }\end{array}$ & $\begin{array}{l}\text { - Commercialized } \\
\text { ELISA technique } \\
\text { (Merck- Millipore }^{\oplus} \text { ) } \\
\text { - Plasma }\end{array}$ & $\begin{array}{l}\text { - Significant decrease in glicentin, } \\
\text { oxyntomodulin, vasoactive intestinal } \\
\text { peptide (VIP) in individuals with abnormal } \\
\text { glucose metabolism } \\
\text { - Significant association between glicentin } \\
\text { and secretin concentrations }\end{array}$ & $\begin{array}{l}\text { Pendharkar } \\
\text { et al. (45) }\end{array}$ \\
\hline $\begin{array}{l}\text { - } 52 \text { lean adults } \\
\text { - } 39 \text { adults with severe or } \\
\text { morbid obesity }\end{array}$ & $\begin{array}{l}\text { Investigate } \\
\text { serum glicentin } \\
\text { concentrations } \\
\text { during adult } \\
\text { obesity and study } \\
\text { its potential link } \\
\text { with metabolic } \\
\text { parameters }\end{array}$ & $\begin{array}{l}\text { - Commercialized } \\
\text { ELISA technique } \\
\text { (Mercodia }^{\oplus} \text { ) } \\
\text { - Serum }\end{array}$ & $\begin{array}{l}\text { - Significant decrease of glicentin } \\
\text { concentration in patients with severe or } \\
\text { morbid obesity compared to lean subjects } \\
\text { - No linear correlation between glicentin } \\
\text { concentration and body mass index, } \\
\text { glycaemic parameters (glycaemia, } \\
\text { insulinemia, C-peptide) or lipid parameters } \\
\text { (total, HDL, LDL-cholesterol, triglyceride) }\end{array}$ & $\begin{array}{l}\text { Raffort et al. } \\
\text { (44) }\end{array}$ \\
\hline $\begin{array}{l}\text { - } 30 \text { adult patients with } \\
\text { severe or morbid obesity, } \\
\text { eligible to bariatric } \\
\text { surgery: } 18 \text { patients had a } \\
\text { Roux-en-Y Gastric Bypass } \\
\text { (RYGB), } 12 \text { patients had } \\
\text { a Laparoscopic Sleeve } \\
\text { Gastrectomy (LSG), } \\
\text { Follow-up at } 3,6 \text { and } 12 \\
\text { months post-surgery }\end{array}$ & $\begin{array}{l}\text { Investigate } \\
\text { fasting circulating } \\
\text { glicentin } \\
\text { variation in } \\
\text { obese patients } \\
\text { who underwent } \\
\text { bariatric surgery }\end{array}$ & $\begin{array}{l}\text { - Commercialized } \\
\text { ELISA technique } \\
\text { (Mercodia }^{\oplus} \text { ) } \\
\text { - Serum }\end{array}$ & $\begin{array}{l}\text { - Significant increase of glicentin at } 6 \text { months } \\
\text { post-surgery, with an effect more marked at } \\
12 \text { months } \\
\text { - Tendency to have a more marked increase } \\
\text { of glicentin after RYGB compared to LSG } \\
\text { - Significant increase of glicentin/ glycaemia, } \\
\text { glicentin/insulinemia, glicentin/C-peptide } \\
\text { ratios after surgery } \\
\text { - Improvement of metabolic parameters } \\
\text { (anthropometric, glycaemic and lipidic) after } \\
\text { surgery } \\
\text { - No direct correlation between glicentin } \\
\text { variation and metabolic parameters variation }\end{array}$ & $\begin{array}{l}\text { Raffort et al. } \\
\text { (43) }\end{array}$ \\
\hline
\end{tabular}




\begin{tabular}{|c|c|c|}
\hline $\begin{array}{l}\text { - } 19 \text { lean adolescents } \\
\text { - } 23 \text { obese adolescents with } \\
\text { normal glucose tolerance } \\
\text { (NGT) } \\
\text { - } 19 \text { obese adolescents with } \\
\text { impaired glucose tolerance } \\
\text { (IGT) } \\
\text { - } 4 \text { obese adolescents with } \\
\text { type } 2 \text { diabetes (T2D) }\end{array}$ & $\begin{array}{l}\text { Explore fasting } \\
\text { and postprandial } \\
\text { plasma } \\
\text { concentrations of } \\
\text { the proglucagon- } \\
\text { derived } \\
\text { hormones } \\
\text { (glucagon, } \\
\text { glicentin, GLP-1) } \\
\text { in adolescents } \\
\text { with obesity }\end{array}$ & $\begin{array}{l}\text { - Commercialized } \\
\text { ELISA technique } \\
\text { (Mercodia }^{\oplus} \text { ) } \\
\text { - Plasma }\end{array}$ \\
\hline
\end{tabular}

- 19 lean adolescents

Explore fasting

plasma

concentrations of

the proglucagon-

hormones

(glucagon,

in adolescents
- No significant difference on fasting glicentin concentrations between lean adolescents and adolescents with obesity and NGT.

- Lower fasting glicentin concentrations in adolescents with obesity and IGT compared to adolescents with obesity and NGT

- Glicentin concentrations after oral glucose tolerance test (OGTT): lower in adolescents with obesity and IGT than those with NGT; peak at 30 minutes in lean adolescents and adolescents with obesity and NGT; peak at 15 minutes in adolescents with obesity and IGT;peak at 60 minutes in adolescents with obesity and T2D

- Ratios of glicentin/glucagon and GLP-1/ glucagon: in fasting: lower ratios in obese adolescents with IGT and T2D than obese adolescents with NGT; during OGTT: lower ratios in obese adolescents with NGT than lean adolescents and lower ratios in obese adolescents with IGT and T2D than obese adolescents with NGT

- Fasting plasma glicentin as a predictor of IGT in adolescents with obesity and normal fasting glucose: $100 \%$ sensitivity and $56 \%$ specificity

- Glicentin basal concentration: early feeding group: higher glicentin concentrations at day 5-6 and day 14 after birth than at day 1 - 2; control group: higher glicentin concentrations at day 14 after birth than at day 1 - 2; higher glicentin concentrations in the early feeding group compared to controls at day 5 - 6 and day 14 after birth infants: 11 infants had early feeding with breast milk within $24 \mathrm{~h}$ after birth, 10 infants had breast milk and the secretion commercialized of gut hormones sandwich ELISA in very-low- Plasma more than $24 \mathrm{~h}$ after birth birthweight - Post prandial glicentin concentration: early feeding group: higher glicentin concentrations after feeding than before feeding at day 5 - 6 and day 14; control group: higher glicentin concentrations after feeding than before feeding at day 14

- Glicentin basal concentration: higher glicentin concentrations in children aged 15 to 29 days, 1 to 5 months versus children aged 1 to 3 years, 4 to 7 years, 8 to 11 years; higher glicentin concentrations in children aged 6 to 11 months versus children aged 1 to 3 years, 8 to 11 years, 12 to 15 years; higher glicentin concentrations in
(42)
Investigate the changes in basal plasma - Nonconcentrations commercialized of glicentin in sandwich ELISA term and preterm - Plasma developing children

$\begin{array}{lll}21 \text { children aged } 15 \text { to } 29 & \\ \text { days, } 16 \text { children aged } 1 & \\ \text { to } 5 \text { months, } 14 \text { children } & \\ \text { aged } 6 \text { to } 11 \text { months, } 16 & \\ \text { children aged } 1 \text { to } 3 \text { years, } & \text { Investigate } & \\ 17 \text { children aged } 4 \text { to } 7 & \text { the changes in } & \\ \text { years, } 18 \text { children aged } 8 \text { to } & \text { basal plasma } & \text { - Non- } \\ 11 \text { years, } 17 \text { children aged } & \begin{array}{l}\text { concentrations } \\ \text { of glicentin in }\end{array} & \text { commercialized } \\ 12 \text { to } 15 \text { years } & \text { term and preterm } & \text { - Plasma } \\ \text { - Term and preterm } & \begin{array}{l}\text { developing } \\ \text { children }\end{array} & \\ \text { infants: } 11 \text { term and } & & \\ \text { normal birthweight, } & \end{array}$
9 low birthweight, 10 very-low-birthweight - Normal birthweight children:14 breastfed and 11 formula-fed very-low-birthweight children versus normal birthweight children at day 1 or 2 after birth - Post prandial glicentin concentration: Tadokoro et higher glicentin concentrations after feeding than before at 1 - 2 days after birth and 5 - 6 days in normal and low-birth-weight children; higher glicentin concentrations after feeding than before at 14 days after birth in very low-birth-weight children; no significant difference in glicentin concentrations between breastfed and formula-fed group 
- 6 normal subjects

- 119 diabetic patients

- 15 gastrectomized patients - 9 with subtotal gastrectomy, 6 with total gastrectomy, 1 with massive small bowel resection
Explore plasma concentration of glicentin in diabetic and gastrectomized patients
- Fasting glicentin concentration: no significant difference on plasma glicentin concentrations between normal subjects and diabetics; no correlation between glicentin concentrations and plasma glucose - Glicentin concentration after OGTT: increase of plasma glicentin in normal subjects; higher peak of glicentin at $30 \mathrm{~min}$ in gastrectomized patients compared to normal subjects; no significant variation of glicentin in the patient who had a massive small bowel resection

- Fasting glicentin: mean amount of total glucagon immunoreactivity eluting at 0.3 $\mathrm{Kd}$ (corresponding to the elution of porcine glicentin), lower in T2D than controls - Glicentin after OGTT: increase of glicentin secretion; mean amount of total glucagon immunoreactivity eluting at $0.3 \mathrm{Kd}$ (corresponding to the elution of porcine glicentin) after OGTT: higher in T2D than controls

VIP - vasoactive intestinal peptide. HDL - high-density lipoprotein. LDL - low-density lipoprotein. RYGB - Roux-en-Y gastric bypass. LSG - laparoscopic sleeve gastrectomy. NGT - normal glucose tolerance. IGT - impaired glucose tolerance. T2D - type 2 diabetes. GLP-1 - glucagon like peptide 1. OGTT - oral glucose tolerance test.

15 years' age and revealed significant variations depending on children age (40). Interestingly, differences on fasting glicentin concentrations were observed between children with very low-birthweight and normal birth weight children, suggesting that glicentin could play a role in gastrointestinal function and growth in the early period of life. In addition, feeding in children may shape and impact on glicentin secretion. Early enteral feeding within 24 hours after birth in very low birth weight children led to higher glicentin basal concentration at day 5-6 and day 14 after birth compared to infants fed more than 24 hours after birth (41). Besides, even if no significant difference in postprandial glicentin concentrations was observed between breastfed and formula-fed children in this study, the potential impact of the nature of food ingested on glicentin secretion cannot totally be excluded.

In addition to its role in intestinal physiology, experimental studies have highlighted the effect of glicentin on glucose metabolism. Some authors addressed its variation in the context of diabetes.
While a first study measured fasting glicentin concentration using a non-commercialized radioimmunoassay combined with chromatography revealed lower glicentin concentrations in type 2 diabetic patients compared to controls (38), others investigators did not find any significant difference using a non-commercialized sandwich ELISA in a larger cohort of patients (39). However, the authors found high glicentin concentrations in a diabetic patient with renal failure suggesting that glicentin may be excreted through the kidney (39). Given the development of new commercialized method which may improve reproducibility of circulating glicentin measurement, it would be worth investigating its variation in large cohorts of patients and different types of diabetes to evaluate its potential usefulness as non-invasive biomarker of the disease.

A recent study aimed at exploring glicentin variation in obese adolescents who had associated metabolic disorders (42). While no significant difference on fasting glicentin concentrations were observed between lean adolescents and adoles- 
cents with obesity and normal glucose tolerance (NGT), adolescents with obesity and impaired glucose tolerance (IGT) had significantly lower glicentin concentration at fasting state and after OGTT compared to those with obesity and NGT (42). Besides, the profile of glicentin secretion observed after OGTT differs between diabetic and healthy subjects and between obese adolescents with NGT, IGT or type 2 diabetes $(38,42)$. These results suggest that glicentin concentrations may be influenced by metabolic disorders and altered glucose homeostasis rather than by the weight or the body mass index itself. This hypothesis is corroborated by the fact that no correlation was observed between body mass index and glicentin concentrations $(44,45)$. In addition, decreased fasting glicentin concentrations was observed in patients with abnormal glucose metabolism after acute pancreatitis, confirming the link between glicentin concentration and defective glucose homeostasis (45). Nevertheless, the impact of glucose homeostasis on glicentin secretion may results from complex mechanisms which are not fully elucidated. Even if glucose intake stimulates glicentin secretion, no linear correlation was found between fasting glicentin and plasma glucose $(39,44)$. Besides, in obese adolescents with IGT and type 2 diabetes, ratios of glicentin/glucagon and GLP-1/glucagon at fasting and after OGTT were lower compared to obese adolescents with NGT. This means that impaired glucose homeostasis may favour the production of pancreatically cleaved proglucagonderived peptides (glucagon) at the expense of intestinally cleaved peptides including glicentin and GLP-1 (42). At last, the authors investigated if glicentin could have a predictive value of IGT in obese adolescents with normal fasting glucose and found that fasting glicentin measurement had sensitivity at $100 \%$ and specificity at $56 \%$ at a cutoff of $22.05 \mathrm{pmol} / \mathrm{L}$, lower concentrations indicating IGT (42). Even if further studies are required, glicentin could potentially represent a biomarker of obesity-related metabolic disorders.

Interestingly, obese patients had lower fasting glicentin concentrations compared to control lean subjects at baseline (44). Moreover, a significant increase of glicentin was observed in obese patients who underwent bariatric surgery at 6 and 12 months' post-intervention (43). Patients receiving a Roux-en-Y gastric bypass (RYGB), which consists in reducing the size of the stomach to a small pouch and shunting the duodenum and the proximal jejunum were compared to patients submitted to a laparoscopic sleeve gastrectomy (LSG), consisting in a longitudinal resection of the stomach. LSG is a restrictive procedure whereas RYGB associates restrictive and malabsorptive effects. The increase of glicentin post-surgery tended to be more marked after RYGB compared to LSG. Hence, bariatric surgery appears to restore, at least partly, glicentin secretion. The impact of digestive surgery on glicentin secretion has been so far poorly investigated. One study reports a higher response of glicentin secretion after OGTT in patients who had a gastrectomy compared to controls whereas no significant response was found in a patient who underwent a massive small bowel resection (39). Taken together, these results corroborate the findings in animal models that the distal small bowel may be a major site of glicentin production (12). In addition, enhanced glicentin secretion after surgery may result from early stimulation of the distal gut mucosa by nutrients as a result of rapid gastric emptying. At last, bariatric surgery has proven its efficiency to improve obesity-related metabolic disorders (46). As glicentin plays a role in glucose homeostasis and reversely metabolic disorders impact on its secretion, further studies are required to determine whether it could be an actor and/or a marker of metabolic improvement observed after bariatric surgery.

\section{Conclusion and future directions}

Glicentin has been much less studied than other proglucagon-derived peptides such as GLP-1, GLP2 or oxyntomodulin. This may be, at least partly, explained by the lack of commercialized detection methods available until recently. Glicentin is produced by L-intestinal cells from the duodenum to the rectum, with a main secretion probably located in the distal small bowel and the proximal colon. Its secretion is stimulated by food intake and experimental studies highlighted its role in intestinal growth, trophicity and motility. In addition to its paracrine function on the digestive tract, gli- 
centin plays a role in metabolism, mainly in glucose homeostasis regulation through exerting incretin-like effects. The implication of glicentin in both intestinal physiology and glucose homeostasis points to various potential applications. Recent advances to assess its circulating variations in human offers promising perspectives to investigate its usefulness as non-invasive biomarker of various pathological states including intestinal diseases such as inflammatory pathologies or colorectal cancers, as well as metabolic disorders like diabetes or obesity. In parallel, advances in fundamental research on proglucagon-derived peptides bio-

\section{References}

1. Murphy KG, Bloom SR. Gut hormones and the regulation of energy homeostasis. Nature 2006;444:854-9. https://doi. org/10.1038/nature05484

2. Holst JJ. Enteroendocrine secretion of gut hormones in diabetes, obesity and after bariatric surgery. Curr Opin Pharmacol 2013;13:983-8. https://doi.org/10.1016/j. coph.2013.09.014

3. Sala PC, Torrinhas RS, Giannella-Neto D, Waitzberg DL. Relationship between gut hormones and glucose homeostasis after bariatric surgery. Diabetol Metab Syndr 2014;6:87. https://doi.org/10.1186/1758-5996-6-87

4. Baggio LL, Drucker DJ. Biology of incretins: GLP-1 and GIP. Gastroenterology 2007;132:2131-57. https://doi. org/10.1053/j.gastro.2007.03.054

5. Holst JJ. Enteroglucagon. Annu Rev Physiol 1997;59:257-71. https://doi.org/10.1146/annurev.physiol.59.1.257

6. Bataille D. Pro-protein convertases in intermediary metabolism: islet hormones, brain/gut hormones and integrated physiology. J Mol Med (Berl) 2007;85:673-84. https://doi. org/10.1007/s00109-007-0167-4

7. Bataille $D$, Dalle $S$. The forgotten members of the glucagon family. Diabetes Res Clin Pract 2014;106:1-10. https://doi. org/10.1016/j.diabres.2014.06.010

8. Whiting L, Stewart KW, Hay DL, Harris PW, Choong YS, Phillips $A R$, et al. Glicentin-related pancreatic polypeptide inhibits glucose-stimulated insulin secretion from the isolated pancreas of adult male rats. Physiol Rep 2015;3:e12638. https://doi.org/10.14814/phy2.12638

9. Graaf C, Donnelly D, Wootten D, Lau J, Sexton PM, Miller LJ, et al. Glucagon-Like Peptide-1 and Its Class B G Protein-Coupled Receptors: A Long March to Therapeutic Successes. Pharmacol Rev 2016;68:954-1013. https://doi.org/10.1124/ pr.115.011395

10. Thim L, Moody AJ. The primary structure of porcine glicentin (proglucagon). Regul Pept 1981;2:139-50. https://doi. org/10.1016/0167-0115(81)90007-0 genesis could provide new pathways involved in glicentin production and secretion and would be useful for a better understanding of its action and its link with other proglucagon-derived peptides. Despite its discovery a few decades ago, the field is still in its infancy and we truly believe that new technologies and further experimental and clinical studies could bring innovative perspectives to use glicentin as a biomarker and/or as a potential therapeutic target of several pathological states.

\section{Potential conflict of interest}

None declared.
11. Gunawardene AR, Corfe BM, Staton CA. Classification and functions of enteroendocrine cells of the lower gastrointestinal tract. Int J Exp Pathol 2011;92:219-31. https://doi. org/10.1111/j.1365-2613.2011.00767.x

12. Wewer Albrechtsen NJ, Kuhre RE, Torang S, Holst JJ. The intestinal distribution pattern of appetite- and glucose regulatory peptides in mice, rats and pigs. BMC Res Notes 2016;9:60. https://doi.org/10.1186/s13104-016-1872-2

13. Whalley NM, Pritchard LE, Smith DM, White A. Processing of proglucagon to GLP-1 in pancreatic alpha-cells: is this a paracrine mechanism enabling GLP-1 to act on beta-cells? J Endocrinol 2011;211:99-106. https://doi.org/10.1530/JOE11-0094

14. Kilimnik G, Kim A, Steiner DF, Friedman TC, Hara M. Intraislet production of GLP-1 by activation of prohormone convertase $1 / 3$ in pancreatic alpha-cells in mouse models of ss-cell regeneration. Islets 2010;2:149-55. https://doi.org/10.4161/ isl.2.3.11396

15. Ohneda A, Takahashi H, Maruyama Y. Response of plasma glicentin to fat ingestion in piglets. Diabetes Res Clin Pract 1987;3:103-9. https://doi.org/10.1016/S01688227(87)80014-1

16. Ohneda A, Kobayashi T, Nihei J, Takahashi H. Effect of intraluminal administration of amino acids upon plasma glicentin. Diabetes Res Clin Pract 1988;5:265-70. https://doi. org/10.1016/S0168-8227(88)80061-5

17. Ohneda A. Response of plasma glicentin to intraduodenal administration of glucose in piglets. Diabetes Res Clin Pract 1987;3:97-102. https://doi.org/10.1016/S01688227(87)80013-X

18. Myojo S, Tsujikawa T, Sasaki M, Fujiyama $Y$, Bamba $T$. Trophic effects of glicentin on rat small-intestinal mucosa in vivo and in vitro. J Gastroenterol 1997;32(3):300-5. https:// doi.org/10.1007/BF02934484 
19. Sasaki M, Fitzgerald AJ, Mandir N, Sasaki K, Wright NA, Goodlad RA. Glicentin, an active enteroglucagon, has a significant trophic role on the small intestine but not on the colon in the rat. Aliment Pharmacol Ther 2001;15:1681-6. https:// doi.org/10.1046/j.1365-2036.2001.01082.x

20. Cheng H, Bjerknes M, Amar J, Gardiner G. Crypt production in normal and diseased human colonic epithelium. Anat Rec 1986;216:44-8. https://doi.org/10.1002/ar.1092160108

21. Park HS, Goodlad RA, Ahnen DJ, Winnett A, Sasieni P, Lee $C Y$, Wright NA. Effects of epidermal growth factor and dimethylhydrazine on crypt size, cell proliferation, and crypt fission in the rat colon. Cell proliferation and crypt fission are controlled independently. Am J Pathol 1997;151:843-52.

22. Fischer JM, Schepers AG, Clevers $H$, Shibata D, Liskay RM. Occult progression by Apc-deficient intestinal crypts as a target for chemoprevention. Carcinogenesis 2014;35:23746. https://doi.org/10.1093/carcin/bgt296

23. Hirotani Y, Taki M, Kataoka K, Kurokawa N, Satoh T, Sasaki K, et al. Effect of rat glicentin on intestinal adaptation in small intestine-resected rats. Ann N Y Acad Sci 1998;865:601-5. https://doi.org/10.1111/j.1749-6632.1998.tb11244.x

24. Hashimoto $N$, Ohyanagi $H$, Kazuyuki S. Effect of glicentin on gut mucosal growth in rats with jejunal and ileal ThiryVella fistulas. J Pediatr Surg 2003;38:579-84. https://doi. org/10.1053/jpsu.2003.50126

25. Chiba M, Sanada Y, Kawano S, Murofushi M, Okada I, Yoshizawa $Y$, et al. Glicentin inhibits internalization of enteric bacteria by cultured INT-407 enterocytes. Pediatr Surg Int 2007;23:551-4. https://doi.org/10.1007/s00383-007-1895-9

26. Pellissier S, Sasaki K, Le-Nguyen D, Bataille D, Jarrousse C. Oxyntomodulin and glicentin are potent inhibitors of the fed motility pattern in small intestine. Neurogastroenterol Motil 2004;16:455-63. https://doi.org/10.1111/j.13652982.2004.00528.x

27. Tomita R, Igarashi S, Tanjoh K, Fujisaki S. Role of recombinant human glicentin in the normal human jejunum: an in vitro study. Hepatogastroenterology 2005;52:1459-62.

28. Rodier G, Magous R, Mochizuki T, Le Nguyen D, Martinez J, Bali JP, et al. Glicentin and oxyntomodulin modulate both the phosphoinositide and cyclic adenosine monophosphate signaling pathways in gastric myocytes. Endocrinology 1999;140:22-8. https://doi.org/10.1210/endo.140.1.6424

29. Rodier G, Magous R, Mochizuki T, Martinez J, Nguyen DL, Bali JP, et al. Effect of glicentin, oxyntomodulin and related peptides on isolated gastric smooth muscle cells. Pflugers Arch 1997;434:729-34. https://doi.org/10.1007/ s004240050458

30. Jarrousse C, Lods N, Michel F, Bali JP, Magous R. Cultured gastrointestinal smooth muscle cells: cell response to contractile agonists depends on their phenotypic state. Cell Tissue Res 2004;316:221-32. https://doi.org/10.1007/s00441-0040859-9

31. Ayachi SE, Borie F, Magous R, Sasaki K, le Nguyen D, Bali JP, et al. Contraction induced by glicentin on smooth muscle cells from the human colon is abolished by exendin (939). Neurogastroenterol Motil 2005;17:302-9. https://doi. org/10.1111/j.1365-2982.2004.00628.x
32. Kirkegaard P, Moody AJ, Holst JJ, Loud FB, Olsen PS, Christiansen J. Glicentin inhibits gastric acid secretion in the rat. Nature 1982;297:156-7. https://doi.org/10.1038/297156a0

33. Ishihara S, Fukuda R, Moriyama N, Ishimura N, Kaji T, Kushiyama $Y$, et al. Helicobacter pylori infection accelerates gene expression of glicentin in the gastric mucosa. Its association with intestinal metaplasia of the stomach. Scand J Gastroenterol 1997;32:460-4. https://doi. org/10.3109/00365529709025081

34. Ohneda A, Ohneda M. Effect of glicentin-related peptides upon the secretion of insulin and glucagon in the canine pancreas. Tohoku J Exp Med 1988;155:197-204. https://doi. org/10.1620/tjem.155.197

35. Thieden HI, Holst JJ, Dich J, Moody A, Sundby F. Effect of highly purified porcine gut glucagon-like immunoreactivity (glicentin) on glucose release from isolated rat hepatocytes. Biochim Biophys Acta 1981;675:163-70. https://doi. org/10.1016/0304-4165(81)90222-1

36. Ohneda A, Kobayashi T, Nihei J. Effect of glicentin-related peptides on glucagon secretion in anaesthetized dogs. Diabetologia 1986;29:397-401. https://doi.org/10.1007/ BF00903352

37. Ohneda A, Ohneda K, Nagasaki T, Sasaki K. Insulinotropic action of human glicentin in dogs. Metabolism 1995;44:4751. https://doi.org/10.1016/0026-0495(95)90288-0

38. Orskov C, Jeppesen J, Madsbad S, Holst JJ. Proglucagon products in plasma of noninsulin-dependent diabetics and nondiabetic controls in the fasting state and after oral glucose and intravenous arginine. J Clin Invest 1991;87:41523. https://doi.org/10.1172/JCl115012

39. Naito $H$, Ohneda A, Kojima $R$, Sato $T$, Sasaki K, Funayama $Y$, et al. Plasma glicentin in diabetic and gastrectomized patients. Regul Pept 1999;79:55-61. https://doi.org/10.1016/ S0167-0115(98)00144-X

40. Tadokoro R, Shimizu T, Hosaka A, Kaneko N, Satoh Y, Yamashiro $Y$. Postnatal and postprandial changes in plasma concentrations of glicentin in term and preterm infants. Acta Paediatr 2003;92:1175-9. https://doi. org/10.1111/j.1651-2227.2003.tb02480.x

41. Shimizu T, Tadokoro R, Kaneko N, Suzuki M, Tanaka K, Shinohara $K$, et al. Effects of extremely early enteral feeding on plasma glicentin levels in very-low-birthweight infants. J Paediatr Child Health 2006;42:636-9. https://doi.org/10.1111/ j.1440-1754.2006.00941.x

42. Manell H, Staaf J, Manukyan L, Kristinsson H, Cen J, Stenlid $R$, et al. Altered Plasma Levels of Glucagon, GLP-1 and Glicentin During OGTT in Adolescents With Obesity and Type 2 Diabetes. J Clin Endocrinol Metab 2016;101:1181-9. https:// doi.org/10.1210/jc.2015-3885

43. Raffort J, Panaia-Ferrari $P$, Lareyre F, Bayer $P$, Staccini $P, F e-$ nichel $P$, et al. Fasting circulating glicentin increases after bariatric surgery. Obes Surg 2016 Dec 16. [cited 2017 Mar 11]. [Epub ahead of print]. https://doi.org/10.1007/s11695016-2493-5

44. Raffort J, Panaïa-Ferrari $P$, Lareyre F, Blois M, Bayer $P$, Staccini $P$, et al. Serum glicentin concentration is decreased in patients with severe and morbid obesity. Ann Clin Biochem 
2017 Mar 21 [cited 2017 Apr 1]. [Epub ahead of print]. https://doi.org/10.1177/0004563217700172

45. Pendharkar SA, Asrani VM, Murphy R, Cutfield R, Windsor JA, Petrov MS. The Role of Gut-brain Axis in Regulating Glucose Metabolism After Acute Pancreatitis. Clin Trans/ Gastroenterol 2017;8:e210. https://doi.org/10.1038/ctg.2016.63

46. Sjostrom L, Lindroos AK, Peltonen M, Torgerson J, Bouchard $C$, Carlsson B, et al. Lifestyle, diabetes, and cardiovascular risk factors 10 years after bariatric surgery. N Engl J Med 2004;351:2683-93. https://doi.org/10.1056/NEJMoa035622
47. DeFronzo RA, Ferrannini E, Zimmet $P$, Alberti KGMM, eds. International textbook of diabetes mellitus. 4th ed. Ava ilable at: http://www.diabetesincontrol.com/international-textbook-of-diabetes-mellitus-4th-ed-excerpt-47-biosynthesis-secretion-and-action-of-glucagon-part-1-of-4/. Accessed March 17th 2017.

48. Shibata C, Naito $H$, Jin XL, Ueno T, Funayama Y, Fukushima $K$, et al. Effect of glucagon, glicentin, glucagon-like peptide-1 and -2 on interdigestive gastroduodenal motility in dogs with a vagally denervated gastric pouch. Scand J Gastroenterol 2001;36:1049-55. https://doi. org/10.1080/003655201750422648 